\title{
Traditional Use and Knowledge Validation of Fodder Trees and Shrubs in NEH Region of India
}

\author{
R. Joseph Koireng ${ }^{1 *}$, Ansar-ul-Haq ${ }^{2}$ and Kh. Priya Devi ${ }^{3}$ \\ ${ }^{1}$ Directorate of Research, Central Agricultural University, Imphal - 795004, Manipur, India \\ ${ }^{2}$ S.K. University of Agricultural Sciences and Technology, \\ Srinagar-190121, Kashmir (J\&K), India \\ ${ }^{3}$ Faculty of Agriculture, Uttar Banga Krishi Viswavidyalaya, Cooch Behar-785 165, India \\ *Corresponding author
}

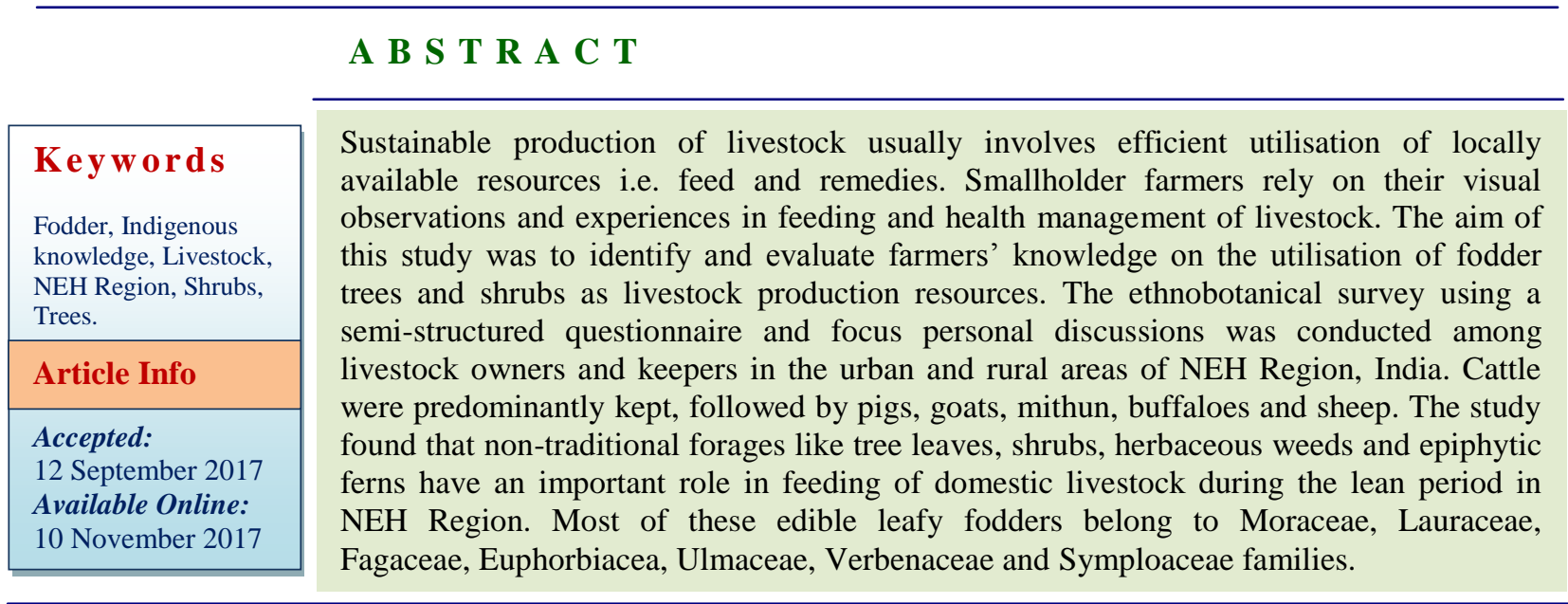

\section{Introduction}

North Eastern states of India particularly in NEH Region livestock rearing were being considered as one of the important homestead activities in the farm household. In the rural household economy, livestock is considered as an inseparable component in the whole farm business, as the production of milk and meat as well as manure, draught and transportation depends on it. It provides nutritional security to farm family and stabilizes farm income too.

As a major source of animal feeds in NEH Region, fodder trees and shrubs are highly valued by farmers. They have deep root systems enabling the extraction of water and nutrients from deeper layer in the soil profile (Teferi et al., 2008). Most of these plants have high crude protein content, ranging from 10 to more than $25 \%$ on dry matter basis (Moleele, 1998). Farmers have an impressive knowledge of browsed species. Involving farmers in the process of data collection is important because as potential users of new technologies to be developed, their knowledge and preferences are critical (Haugerud and Collinson, 1990). However, some of the knowledge is liable to be 
distorted or lost completely if transfer is not done continuously.

In the present study knowledge on utilisation of trees and shrubs as feed for livestock in $\mathrm{NEH}$ Region has been described.

\section{Materials and Methods}

The information regarding indigenous knowledge was gathered through literature survey and field visits. Individual interviews were conducted among livestock owners and keepers. Issues related to the knowledge on trees and shrubs such as availability and acceptability by the animals were discussed during the interviews. Plant samples which were utilised as fodder were collected from each farmers and identification was done at the CAU, Imphal and confirmed with the help of plant taxonomist from Manipur University.

\section{Results and Discussion}

Different fodder trees and shrubs contribute to the ration of livestock during different seasons. The farmers in the study area identified six seasons based on local feeding. In general, there are two seasons of scarce feed resources reported in the study area: the dry summer season covering a period from early March to mid-May, and winter from early December to the end of February. Fodder trees contribute to livestock rations, especially during these scarce seasons.

The use of some fodder trees extends beyond the typical scarce season. Some of the shrubs are being freely browsed throughout the entire year, whereas others are lopped and provide foliage for intensive feeding during the scarce seasons. Table 1 summarizes the availability, their habitat, favoured plant part, animal species consume on it and loping cycle during different seasons. Moraceae has appeared to be the dominant family, followed by Lauraceae and Fagaceae. The identification of more fodder trees is important since, trees have two characteristics, which make them useful particularly during drought. Firstly the trees able to draw as moisture and mineral from deeper layer of the soil which are out of reach for grasses, secondly, the leaves of most trees retain their nutritive value even when they are mature. Trees and shrubs provide fodder which is of great importance during period of nutritional stress in the dry season when the nutritional value of dormant grasses is low. In addition to tree and shrub leaves, cattle and goats consume the fruits of many trees like Quercus glauca, Myrica esculeta, Ficus palmate, Ficus benghalensis, Celtis tetranda and ripe fruits of Meyna spinosa. So far the lopping cycle is concerned; it varies from species to species. Plant species belonging to Ficus, Artocarpus and Bauhinia had greater importance in providing more edible biomass (Verma et al., 1982). Most of the fodder species have the lopping cycle throughout the lean period (October-May).

Majority of the species have longer lopping cycle and higher palatability, which are taken as positive attributes of the fodder trees by the breeders. The main impact of feeding such fodder during lean period as supplementary item has been observed to have maintained the sustainable production of cattle product in $\mathrm{NEH}$ Region. In the traditional farming system of the NEH Region of India, different types of fodder trees and shrubs are found and used differently by various landowning and landless social segments. The landless herders, who annually rear thousands of cattle, sheep and goats, are at risk because of decreasing lowland grazing areas and fodder availability along trekking routes and resting sites. This paper demonstrates that indigenous tree and shrub species have a high potential in sustaining a pastoral system in need of alternatives to shrinking grazing areas. It is also imperative that indigenous knowledge is documented and evaluated before it is lost. 
Table.1 Important fodder trees and shrubs of NEH Region, favoured plant part, animal species feeding on it and their lopping cycle

Plant species

Alnus nepalensis D.Don

Alternanther philoxeroids Griseb

Antidesma acidum Retz

Ardisia cororala Roxb

Artocarpus chaplasa Roxb.

Artocarpus gomezianus Wall. Ex Trecul

Artocarpus heterophyllus Lamk.

Averrhoea carambola Linn

Bambusa olivereina Gamble

Betula alnoides Buch.-Ham.ex D.Don

Bridelia pubecens Kutz

Buddleja asiatica Lour.

Callicarpa arborea Roxb.

Castronopsis indica A. DC.

Castronopsis kurzii (Hance) S.M. Biswas Castronopsis tribuloides (Sm.) DC.

Celtis tetranda Roxb.

Celtiscinua australis

Cinnamomum bejolghota (Buch.-Ham.)

Sweet.

Cinnamomum gladuliferum (Nees)

Meissn.

Cinnamomum pauculorum Nees.

Emblica officialis Gaertn.

Ficus auriculata Lour.

Ficus benghalensis Linn

Ficus bhotanica King ex Hook.f.

Ficus fulva Reinwardt.

Ficus hispida Linn.f.

Ficus oligodon Miq.

Ficus palmata Linn

Ficus religiosa Linn.

Ficus semicordata J.S. Sm.

Ficus virens Ait.

Fraxinus floribunda Wall.

Glochidion assamicum Hook.f.

Glochidion sphaerogynum Kurz

Leucaena glauca Benth

Litsea monopetala (Roxb.) Pers.

Mallotus phillipenssis (Lam.) Muell.-Arg.

Meyna spinosa

Morus australis Poir.

Morus serrata Roxb.

Persea bombycina (King ex. Hook.f.)

Kosterm.

Persea kingii (Hook.f.) Kosterm.

Persea odoratissima (Nees.) Kosterm.

Phoebe cuminate (Nees.) Nees.

Quercus glauca Thunb.

Quercus griffithii Hook.f. \& Thoms. ex

DC.

Quercus serrata Thunb.

Spondias Mangifera

Symplocus paniculata

Trema cannabina Lour.

Trema orientalis (Linn.) Bl.

Vitex penducularis Wall. Ex Sch.

\begin{tabular}{|c|c|}
\hline Family & Plant parts used \\
\hline Betulaceae & $\mathbf{L}$ \\
\hline Amaranthaceae & Whole part \\
\hline Euphorbiaceae & $\mathbf{L}, \mathbf{F}$ \\
\hline Myrsinaceae & $\mathbf{L}$ \\
\hline Moraceae & $\mathbf{L}$ \\
\hline Moraceae & $\mathbf{L}, \mathbf{F}$ \\
\hline Moraceae & $\mathbf{L}$ \\
\hline Oxalidaceae & $\mathbf{L}$ \\
\hline Poaceae & $\mathbf{L}$ \\
\hline Betulaceae & $\mathbf{L}$ \\
\hline Euphorbiaceae & $\mathbf{L}, \mathbf{F}$ \\
\hline Loganiaceae & $\mathbf{L}$ \\
\hline Verbenaceae & $\mathbf{L}, \mathbf{F}$ \\
\hline Fagaceae & $\mathbf{L}$ \\
\hline Fagaceae & $\mathbf{L}$ \\
\hline Fagaceae & $\mathbf{L}$ \\
\hline Ulmaceae & $\mathbf{L}, \mathbf{F}$ \\
\hline Ulmaceae & $\mathbf{L}$ \\
\hline Lauraceae & $\mathbf{L}$ \\
\hline Lauraceae & $\mathbf{L}$ \\
\hline Lauraceae & $\mathbf{L}$ \\
\hline Euphorbiaceae & $\mathbf{L}, \mathbf{F}$ \\
\hline Moraceae & $\mathbf{L}, \mathbf{F}$ \\
\hline Moraceae & $\mathbf{L}, \mathbf{F}$ \\
\hline Moraceae & $\mathbf{L}$ \\
\hline Moraceae & $\mathbf{L}$ \\
\hline Moraceae & $\mathbf{L}$ \\
\hline Moraceae & F, L \\
\hline Moraceae & $\mathbf{L}, \mathbf{F}$ \\
\hline Moraceae & $\mathbf{L}$ \\
\hline Moraceae & $\mathbf{L}$ \\
\hline Moraceae & $\mathbf{L}$ \\
\hline Oleaceae & $\mathbf{L}$ \\
\hline Euphorbiaceae & $\mathbf{L}$ \\
\hline Euphorbiaceae & $\mathbf{L}$ \\
\hline Mimosaceae & $\mathbf{L}$ \\
\hline Lauraceae & $\mathbf{L}$ \\
\hline Euphorbiaceae & $\mathbf{L}$ \\
\hline Rubiaceae & $\mathbf{L}, \mathbf{F}$ \\
\hline Moraceae & $\mathbf{L}$ \\
\hline Moraceae & $\mathbf{L}$ \\
\hline Lauraceae & $\mathbf{L}$ \\
\hline Lauraceae & $\mathbf{L}$ \\
\hline Lauraceae & $\mathbf{L}$ \\
\hline Lauraceae & $\mathbf{L}$ \\
\hline Fagaceae & $\mathbf{L}$ \\
\hline Fagaceae & $\mathbf{L}$ \\
\hline Fagaceae & $\mathbf{L}, \mathbf{F}$ \\
\hline Simaroubaceae & $\mathbf{L}$ \\
\hline Symploaceae & $\mathbf{L}$ \\
\hline Ulmaceae & $\mathbf{L}$ \\
\hline Ulmaceae & $\mathbf{L}$ \\
\hline Verbenaceae & $\mathbf{L}$ \\
\hline
\end{tabular}

Animal species

Cattle goats Cattle

Goats, cattle Cattle Cattle

Goats, cattle Cattle

Cattle, Goat

Cattle, Goat, Sheep, Mithun Cattle

Goats, cattle Cattle

Goats, cattle

Goats, cattle

Goats, cattle Cattle

Goats, Cattle, Mithun

Cattle, Goat, Sheep

Goats, Cattle

Lopping Cycle

April - May

Jan-Dec

Oct - May

March-May

Oct - May

Oct - May

Oct - May

April-Sept

Jan-Dec

Dec - May

Jan - May

Oct - May

Jan - May

Feb - May

Feb - May

Oct - May

March - May

May-Sept

Oct - May

Goats, Cattle

March - May

Goats, Cattle

Goats, Cattle, Mithun

Goats, cattle

Goats, cattle

Cattle, goats

Goats, cattle

Goats, cattle

Cattle, goats

Cattle, Goat, Sheep Cattle

Cattle, goats

Cattle

Goats

Cattle, goats Cattle

Cattle, Goat, Sheep

Cattle, Goat Cattle

Cattle, Goat, Sheep

Goats, cattle

Goats, cattle, Mithun

Cattle

Oct - May

April - May

Oct - May

Oct

Oct

Oct

March - May

Feb - May

April-Sept

April - May

Oct - May

Oct - May

March - May

Oct - May

March - May

April-August

Oct - May

Dec - May

May-Oct

March - May

March - May

Oct - May

Cattle

Cattle

Cattle

cattle

Oct - May

Oct - May

Oct - May

Cattle, goats

Jan - May

Cattle, goats

Cattle, Goat, Sheep, Mithun

Cattle, Goats

Cattle, Goats

Cattle

Cattle
April - May

April - Sept

April-August

March - April

March - May

Oct - May

April - May 


\section{Acknowledgments}

Authors acknowledge the local farmers and livestock keepers for sharing their knowledge and providing facility for research and also thanks to staff of botany department, Manipur University for their help in plant identification. The gratitude is shown to his colleague under AICRP-FC \& U, DOR, CAU, Imphal for assisting during the research programme.

\section{References}

Chetri, RB, 2010 Some fodder yielding trees of Meghalaya, Northeast India, Indian Journal of Traditional Knowledge, 9(4) 786-790.

Haugerud A and Collinson M P 1990 Plants, genes, and people: Improving the relevance of plant breeding in Africa. Exploration Agriculture 26: 341-362.

Moleele NM 1998 Encroacher woody plant browse as feed for cattle. Cattle diet composition for three seasons at Olifants Drift, south-east Botswana. Journal of Arid Environments 40: 255-268.

Terefi A, Solomon M and Lisanework N 2008 Management and utilization of browse species as livestock feed in semi-arid district of North Ethiopia. Livestock Research for Rural Development, 20.

Verma, A., B.P.S. Yadav, K.T. Sampath and D.J. Roy. 1982. Livestock feed and feeding habits in north-eastern hills of India. Res. Bull. 17, ICAR Research Complex for NEH Region, Shilong, India p. 1-100.

\section{How to cite this article:}

Joseph Koireng, R., Ansar-ul-Haq and Priya Devi, Kh. 2017. Traditional Use and Knowledge Validation of Fodder Trees and Shrubs in NEH Region of India. Int.J.Curr.Microbiol.App.Sci. 6(11): 1538-1541. doi: https://doi.org/10.20546/ijcmas.2017.611.182 